\title{
Effects of Nigella sativa on heat-induced testis damage in mouse
}

\author{
Mohajeri D ${ }^{1}$, Kaffashi Elahi R ${ }^{2}$ \\ Department of Pathobiology, College of Veterinary Medicine, Tabriz Branch, Islamic Azad University, \\ Tabriz, Iran. daryoushmohajeri@yahoo.com
}

\begin{abstract}
Background: Infertility is one of the major health problems.
Objectives: The aim of this study was to evaluate the effects of Nigella sativa on heat-induced testicular damage. Methods: Forty male mice were randomly divided into the four equal groups as Control, Heat stressed and, Heated and treated with Nigella sativa $10 \%$ and $20 \%$ in diet. The scrotum of mice except to the control mice were immersed for $15 \mathrm{~min}$ in a water bath at $43^{\circ} \mathrm{C}$. Animals in the control group were treated identically except that the water bath was maintained at $23^{\circ} \mathrm{C}$. Fifty days after the heating, blood samples were collected for testosterone levels. Testes were removed for the measurement of seminiferous tubules diameter and percentage of spermatogenesis and oxidant/antioxidant status.

Results: Heating stress significantly reduced blood testosterone level and increased lipid peroxidation product and decreased antioxidant activities of superoxide dismutase, catalase and glutathione peroxidase $(p<0.01)$. Nigella sativa treatment significantly increased blood testosterone level and decreased testis malondialdehyde level and increased antioxidant enzymes activities $(p<0.05)$. In the mice treated with Nigella sativa, testes illustrated normal spermatogenesis and structure.

Conclusion: The results indicated that supplementation of Nigella sativa in diet improves spermatogenesis and antioxidant status after a short exposure of the mouse testis to heat (Tab. 1, Fig. 4, Ref. 45). Text in PDF www.elis.sk.

Key words: heating, testis, Nigella sativa, antioxidants, mouse.
\end{abstract}

\section{Introduction}

Infertility is one of the major health problems with the medical and economic significance (1). Testicular damage caused by heat, is considered to be one of the causes of infertility in men and the most of mammalian (2). In the most mammalian species, a relatively low temperature is required for normal spermatogenesis and sperm fertility. Studies have found that the temperature of the scrotum in the most mammals is 4 to $5{ }^{\circ} \mathrm{C}$ lower than the abdominal cavity temperature (3). However, exposing testes to or above body temperature by localized heating (4), experimental cryptorchidism (5), or varicocele (6) led to the arrest of spermatogenesis and cause a temporary or permanent sterility (5). Cellular mechanism, by which heat stress damage the testes, are not fully understood (7). Production of free radicals and reactive oxygen species (ROS), including superoxide anion and hydrogen peroxide, can induce positive changes in sperm function $(8,9)$.

${ }^{1}$ Department of Pathobiology, College of Veterinary Medicine, Tabriz Branch, Islamic Azad University, Tabriz, Iran, and ${ }^{2}$ Department of Clinical Sciences, College of Veterinary Medicine, Tabriz Branch, Islamic Azad University, Tabriz, Iran

Address for correspondence: D. Mohajeri, PhD, Department of Pathobiology, College of Veterinary Medicine, Tabriz Branch, Islamic Azad University, P.O. Box: 5157944533, Tabriz, Iran.

Phone: +98.0411.6373339, Fax: +98.0411.6373935

Acknowledgements: The authors would like to thank Tabriz Branch, Islamic Azad University for the financial support of this research, which is based on a research project contract (13-11-5-14966).
However, excessive production of ROS can be harmful to sperm, causing male sterility. Research conducted by Ikeda et al (1999) showed a very effective role of reactive oxygen radicals in germ cell testicular damage caused by heat stress (5). Beneficial effects of antioxidants and free radical scavengers on damage caused by thermal stress and the improvement of the fertility in male rats were reported by Setchell and Wahab-Wahlgren (10). Reports are mainly focused on the use of various antioxidants (11) and extracts of herbs or other agents containing antioxidant properties (12). The usage of the plants in the treatment of infertility, increasing of fertility and sexual potency is a believer in the old ancestral (13). Nigella sativa Linn. from the Ranunculaceae family, is commonly known as Black seed in traditional medicine. In India, Arabic countries, Europe and Iran, Nigella sativa seeds and oil are traditionally used in treating diseases such as asthma, diabetes, tumor, bronchitis, gastrointestinal disturbances, impotence and painful menstruation. Nigella sativa is also used as carminative, diuretic and anti-parasitic agent $(14,15)$. In many diseases, such as cirrhosis, hepatitis and chemical poisoning, in which free radicals are produced; the antioxidant properties of Nigella sativa could be very useful (16). It has been shown that antioxidant effects of Nigella sativa oil are 4-5 times greater than its essence (17). Also, due to the presence of fatty acids and compounds such as tocopherols, carotenoids, metal ions and phosphorus components in smaller amounts, fresh and intact plant and most of its oil is resistant against to oxidation (18).

Considering the numerous beneficial effects and particularly antioxidant activity of Nigella sativa, it is believed that the seeds 
of this plant are capable to protect the testes against heat-induced oxidative damage. Therefore, the present study evaluated the protective effects of Nigella sativa against damage caused by heat stress in mouse testis.

\section{Materials and methods}

\section{Chemicals}

All chemicals were purchased from Sigma- Aldrich Company (St. Lou is, MO, USA) except those otherwise indicated.

\section{Plant material}

Nigella sativa were obtained from Herbal Drug Stores. The seeds were identified and confirmed by a botanist in the Biology Department of Tabriz University of Medical Science, as black seed (Nigella sativa Linn.).

\section{Animal treatment}

A total of 40 adult Balb/C mice, 30-35 gr were housed in colony rooms with $12 / 12 \mathrm{~h}$ light/dark cycle at $21 \pm 2{ }^{\circ} \mathrm{C}$ and fed with laboratory pellet chow and given water ad libitum. Investigations using experimental animals were conducted in accordance with the internationally accepted principles for laboratory animal use and care as found in the United States guidelines (United States National Institutes for Health publication no. 85-23, revised in 1985). After a week of adaptation to the new conditions, animals were randomly allocated to four experimental groups each containing 10 mice including: 1 - Control, 2 - Heat stress, 3 - Heated and treated with a low dose of ground Nigella sativa; and 4 - Heated and treated with a high dose of ground Nigella sativa. With the start of the experiment, the Groups 1 and 2 used the standard basal diet and in the groups 3 and 4 respectively, $10 \%$ and $20 \%$ were added to the basal diet. After 10 days, the mice were anaesthetized with intraperitoneal administration of xylazine $(10 \mathrm{mg} / \mathrm{kg}$, Alfasan, Holland) and ketamine (100 mg/kg, Rotexmedica, Germany), then, the scrotum and hind legs of mice except to the control mice were immersed for $15 \mathrm{~min}$ in a water bath at $43{ }^{\circ} \mathrm{C}$. Animals in the group 1 were treated identically except that the water bath was maintained at $23{ }^{\circ} \mathrm{C}(19)$. Post heating treatment of the mice with the mentioned diet was continued for 50 consecutive other days. At the end of experiment, all mice groups were sacrificed by cervical dislocation.

\section{Biochemical assays}

Blood testosterone levels

In order to determine serum testosterone levels, the trunk blood was collected and $1 \mathrm{ml}$ of blood was distributed into tubes containing an anticoagulant agent, followed by centrifugation at $2500 \mathrm{rpm}$ for $15 \mathrm{~min}$ at $30^{\circ} \mathrm{C}$. Serum testosterone was assayed by radioimmunoassay (RIA). Testosterone levels were analyzed using RIA kits purchased from Immunotech (Marseille, France).

Measurement of malondialdehyde (MDA) and antioxidant enzymes activities

Left testes were excised immediately, washed with ice-cold physiologic saline solution $(0.9 \%, \mathrm{w} / \mathrm{v})$, blotted and weighed.
About $1 \mathrm{~g}$ of testis was cut into small pieces, homogenized with an Ultra Turrax homogenizer in $2 \mathrm{ml}$ ice-cold appropriate buffer (TBS, pH 7.4) and centrifuged at $9000 \mathrm{~g}$ for $15 \mathrm{~min}$ at $4{ }^{\circ} \mathrm{C}$. Supernatants were collected and stored at $-80{ }^{\circ} \mathrm{C}$ until use for enzyme assays. Concentrations of MDA, an index of lipid peroxidation and oxidative stress, in testis were determined spectrophotometrically by the method of Buege and Aust (20).

Superoxide dismutase (SOD) activity in tissue extracts was assayed spectrophotometrically as described by Beyer and Fridovich (21). This method is based on the capacity of SOD to inhibit the oxidation of nitroblue tetrazolium (NBT). One unit of SOD represents the amount of enzymes required to inhibit the rate of NBT oxidation by $50 \%$ at $25^{\circ} \mathrm{C}$. The activity was expressed as units $/ \mathrm{mg}$ protein.

Testis catalase (CAT) activities were measured according to Aebi (22). Hydrogen peroxide $\left(\mathrm{H}_{2} \mathrm{O}_{2}\right)$ disappearance was monitored kinetically at $240 \mathrm{~nm}$ for $1 \mathrm{~min}$ at $25^{\circ} \mathrm{C}$. The enzyme activity was calculated using an extinction coefficient of $0.043 \mathrm{mM}^{-1} \mathrm{~cm}^{-1}$. One unit of activity is equal to the $\mathrm{mmol}$ of $\mathrm{H}_{2} \mathrm{O}_{2}$ destroyed $/ \mathrm{min} / \mathrm{mg}$ protein.

Glutathione peroxidase (GPx) activity in tissue extracts was assayed according to the method of Flohe and Gunzler (23). The activity was expressed as $\mathrm{mmol}$ of GSH oxidized $/ \mathrm{min} / \mathrm{mg}$ of protein at $25^{\circ} \mathrm{C}$.

\section{Histopathological evaluation}

Right testes were removed gently for histological analysis. The sample was fixed by immersing it in $10 \%$ neutral-buffered formalin. The sample was then embedded in paraffin, sliced into $5 \mu \mathrm{m}$ sections, and stained with hematoxylin-eosin for blinded histological assessment. Histopathological evaluation of testes was done using two parameters by an expert pathologist in a blind fashion. The first parameter was the mean seminiferous tubules diameter in each testis. The ten smallest, roundest tubules were identified and measured with an ocular micrometer under the light microscopy. The mean diameter, in microns, was then determined for each group. The second parameter was the percentage of spermatogenesis. For this purpose, two hundred seminiferous tubules were examined under the light microscopy. The presence of spermatozoa within the seminiferous tubule was considered as the evidence of spermatogenesis. Lack of spermatozoa even in the presence of orderly progression of primary and secondary spermatocytes was not considered as the evidence of spermatogenesis for the purpose of this experimental study (24).

\section{Statistical analysis}

The results were expressed as the mean \pm SD. The significance of differences among the groups was analyzed statistically by the One-way Analysis of Variance, followed by followed by Tukey's post-hoc multiple comparison test. The differences were considered statistically significant if $\mathrm{p}<0.05$.

\section{Results}

\section{Serum testosterone level}

The serum testosterone levels in the control, heat stress as well as heated and treated with Nigella sativa groups are shown in Figure 1. 


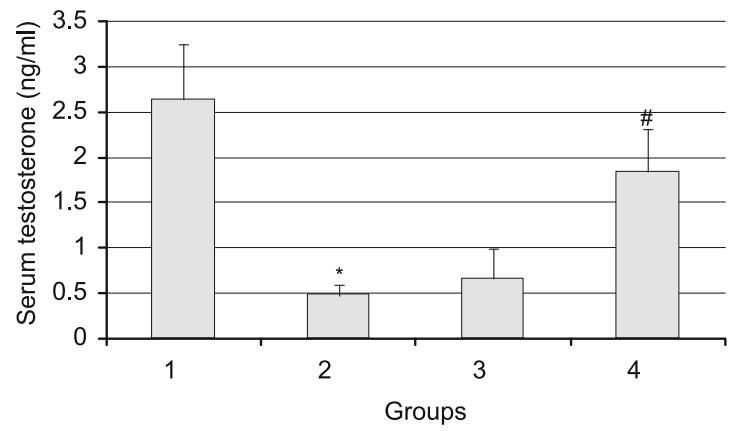

Fig. 1. Effect of ground Nigella sativa on serum testosterone level following heat stress. Values are mean $\pm S D(n=10)$. Values are statistically * $\mathrm{p}<0.01$ vs. control group, \# $\mathrm{p}<0.05$ vs. heat stress group.

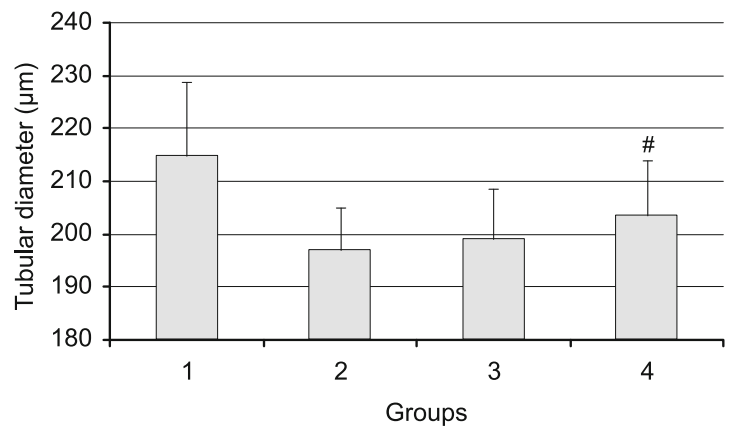

Fig. 2. Effect of ground Nigella sativa on seminiferous tubules diameter $(\mu \mathrm{m})$ following heat stress. Values are mean $\pm S D(n=10)$. * $p<$ 0.01 vs. control group, \# $p<0.05$ vs. heat stress group.

In heat stress mice, the serum testosterone level significantly $(p<0.01)$ decreased compared to the control mice. In the heated and treated with low dose of ground Nigella sativa mice (group 3 ) no significant improvement was observed in comparison with heat stress mice. However, a significant improvement $(\mathrm{p}<0.05)$ was observed in the mice heated and treated with high dose of ground Nigella sativa (group 4) compared to the heat stress mice.

Lipid peroxidation and activities of antioxidant enzymes in testis

Effect of ground Nigella sativa on lipid peroxidation and activities of antioxidant enzymes in testis following heat testicular stress are shown in the Table 1. The MDA level in testis of heat stress mice significantly $(p<0.01)$ increased compared to the control group. In the mice heated and treated with low dose of

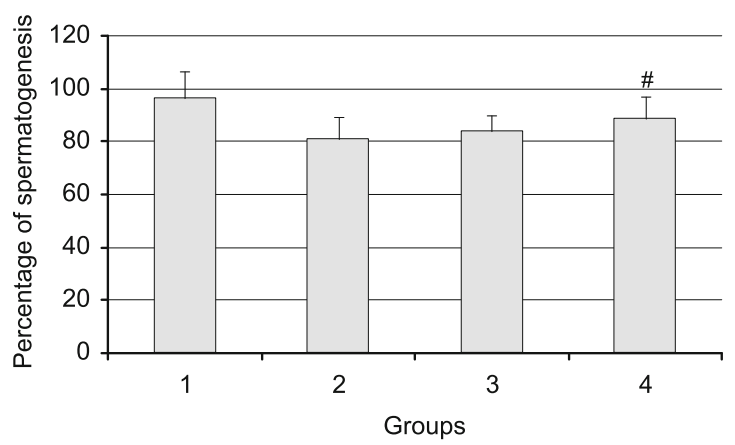

Fig. 3. Effect of ground Nigella sativa on percentage of spermatogenesis following heat stress. Values are mean \pm SD $(n=10) . * p<0.01$ vs. control group, \# $p<0.05$ vs. heat stress group.

ground Nigella sativa (group 3) no significant improvement was observed. The administration of ground Nigella sativa in a high dose significantly $(p<0.05)$ decreased the level of MDA in testis of the mice, as compared to the heat stress group. The activity of SOD was significantly lower $(\mathrm{p}<0.01)$ in testis of the heat stress mice compared to the control group. Similarly, the activities of CAT and GPx were significantly decreased in heat stress mice as compared to the control group. In the mice heated and treated with low dose of ground Nigella sativa (group 3) no significant improvement were observed in testicular antioxidant enzymes activities as compared to the heat stress mice. However, the treatment with a high dose of ground Nigella sativa resulted in a significant restoration $(\mathrm{p}<0.05)$ of all these enzymes.

\section{Seminiferous tubules diameter and spermatogenesis}

The mean seminiferous tubules diameter was reduced in the testes of heat stress group in comparison with the control mice ( $p$ $<0.01$ ). The mean seminiferous tubules diameter showed a marked increase in the in the mice heated and treated with high dose of ground Nigella sativa $(\mathrm{p}<0.05)$, but there was not significant recovery in mean seminiferous tubules diameter of heated and treated with low dose of ground Nigella sativa group as compared to the heat stress mice (Fig. 2).

The percentage of spermatogenesis in the testes of heat stress mice was reduced in comparison with the control group $(\mathrm{p}<$ 0.01 ). The percentage of spermatogenesis was increased in the mice heated and treated with high dose of ground Nigella sativa $(p<0.05)$, but there was not significant improvement in the percentage of spermatogenesis in heated and treated with low dose

Tab. 1. Effect of ground Nigella sativa on antioxidant status following testis heat stress.

\begin{tabular}{|c|c|c|c|c|}
\hline \multirow[b]{2}{*}{ Group } & \multicolumn{4}{|c|}{ Biochemical parameters } \\
\hline & $\begin{array}{c}\text { MDA } \\
\mathrm{nmol} / \mathrm{mg} \text { protein }\end{array}$ & $\begin{array}{c}\text { SOD } \\
\mathrm{U} / \mathrm{mg} \text { protein }\end{array}$ & $\begin{array}{c}\text { CAT } \\
\text { mmoles } \mathrm{H}_{2} \mathrm{O}_{2} / \mathrm{min} / \mathrm{mg} \text { protein }\end{array}$ & $\begin{array}{c}\text { GPx } \\
\text { mmolesGSH/min/mg protein }\end{array}$ \\
\hline 1 & $0.47 \pm 0.03$ & $1.40 \pm 0.25$ & $31.50 \pm 1.40$ & $0.41 \pm 0.09$ \\
\hline 2 & $0.74 \pm 0.18^{*}$ & $0.71 \pm 0.10^{*}$ & $18.70 \pm 0.90^{*}$ & $0.18 \pm 0.07^{*}$ \\
\hline 3 & $0.69 \pm 0.14$ & $0.84 \pm 0.08$ & $22.30 \pm 1.10$ & $0.21 \pm 0.05$ \\
\hline 4 & $0.58 \pm 0.04^{\#}$ & $1.15 \pm 0.28^{\#}$ & $28.20 \pm 3.10^{\#}$ & $0.31 \pm 0.03^{\#}$ \\
\hline
\end{tabular}

Values are the mean $\pm \operatorname{SD}(\mathrm{n}=10) .{ }^{*} \mathrm{p}<0.01$ vs control group, $\# \mathrm{p}<0.05$ vs heat stress group. 

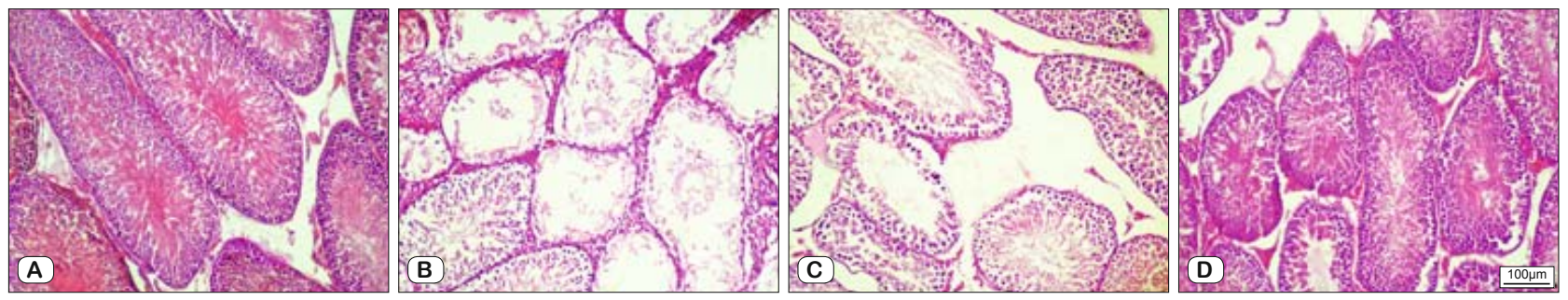

Fig. 4. Photomicrographs of H\&E stained sections of mouse testis. (A) Group 1: Histological structure shows normal structure. (B) Group 2: Degenerative changes and severe necrosis of seminiferous tubules is prominent. (C) Group 3: Some of the seminiferous ducts are degenerated and reduced germinal layers thickness of tubules is seen. (D) Group 4: Some of the seminiferous tubules show mild degenerative changes $(\mathrm{x} 250 ; \mathrm{Bar}=100 \mu \mathrm{m})$.

of ground Nigella sativa group as compared to the heat stress mice (Fig. 3).

\section{Histopathological observations}

The control animals exhibited normal testicular structure in histopathological examination. The testes of the mice in the Heat stress group showed degenerative changes with spermatic arrest in most of the seminiferous ducts. Distention of interstitial space with some evidence of edema and thickening of the capsule was prominent. Treatment with a high dose of ground Nigella sativa improved the damage and structure of the testes was near to normal. However, in some areas, seminiferous tubules were slightly shrunk and tubular basement membranes had irregular outline. The appearance of interstitial tissue of testes in the low dose ground Nigella sativa treatment group was similar to the heat stress group and some of the seminiferous tubules were degenerated (Fig. 4).

\section{Discussion}

The results of the present study supported the previous reports denoting that a short exposure of the mouse testis to heat can induce considerable pathologic changes $(19,25)$. This study demonstrated that administration of ground Nigella sativa in diet of mice for 60 days caused the increase of serum testosterone level and improved testicular damage caused by heating as compared with the Heat stress group in a dose dependent manner. However, in the present study, administration of ground Nigella sativa in diet of male mice caused the enhancing in enzymatic antioxidant defense system. Similar results were obtained in a previous report of male diabetic rats (26). Also, these findings agree with those reported by AlSa'aidi et al (2009) and Mohammad et al (2009) who demonstrated that Nigella sativa produced an increase on fertility and reproductive system in adult male rat $(27,28)$. Histopathological findings in the present study revealed that the spermatogenic damage caused by exposure of the mouse testis to heat could be improved by the administration of ground Nigella sativa in diet. It has been previously revealed that the pachytene spermatocytes and early spermatids were the cells in the testis, which were most susceptible to heat (29). Early studies have shown that heat induced cell death in the testis (30). Cell death had been observed in meiotic primary spermatocytes and mitotic spermatogonia (31). It was originally claimed that the cell death following heating was not an apoptosis but necrosis, although this was not accompanied by inflammation (32). However, subsequent studies have shown that apoptosis was involved (33-35). Take in all, the mechanism of cell death appears to be apoptosis, not necrosis, and may involve reactive oxygen species (ROS), the tumour suppressor protein p53, nitric oxide synthase (NOS), the translocation of the proapototic factor Bax from the cytoplasm to a perinuclear position, the release of cytochrome $\mathrm{c}$ from mitochondria and several caspases (7). The effects of antioxidants and the free radical trapping agents were studied before and during local heating of the testes (10). Antioxidants have been shown to reduce the damage to DNA in infertile patients (36). According to the previous reports, Nigella sativa possesses antioxidant activity $(37,38)$. Elevation in MDA level in testis of scrotal heat stressed mice suggested that oxidative stress due to free-radical damage was one of the possible mechanisms in the pathophysiology of heat induced testicular damage. On administration of ground Nigella sativa, the MDA levels have decreased. This indicated that in the presence of Nigella sativa in the diet there was the improvement in the oxidative stress. The data of our study also revealed that treatment by ground Nigella sativa markedly improved the antioxidant status of testis in the mice exposed to scrotal heat stress. The increase in antioxidant enzymes activity and the decrease in MDA level in testis of Nigella sativa treated mice exposed to scrotal heat stress underlined its anti-lipid peroxidative and antioxidative properties. Therefore, another explanation for improvement of testicular damage in Nigella sativa treated mice exposed to scrotal heat stress is the reduced level of testicular MDA and restoration of antioxidant enzymes activities. The antioxidant activities of Nigella sativa were previously demonstrated by Salem (2005) who revealed that the oil of Nigella sativa and its active ingredients, in particular thymoquinine (TQ), encompassed antioxidant effects by enhancing the scavenger system leading to antitoxic effects (39). In the same way, Kanter (2008) has reported that Nigella sativa decreased the LPO and hepatic marker enzymes, and increased the antioxidant defense system activity (40). Same authors also demonstrated that Nigella sativa treatment decreased tissue malondialdehyde and prevented inhibition of superoxide dismutase, glutathione peroxidase and catalase enzyme activities following the experimental spinal cord injury in rats (41). 
According to the previous records, the improvement of reproductive functions of male rats by Nigella sativa was probably related to its constituents of proteins, vitamins like A, B and $\mathrm{C}$, in addition to the presence of important minerals like zinc, copper and magnesium, which increased reproductive organs weight and to the fact that Nigella sativa seeds contained alkaloids and phenols, which stimulated the secretion of testosterone (42-44).

Finally, since the time needed for initiation of stem cell division to formation of spermatozoa is around 35 days for mice (45), our selected period of time in present study provided enough time to supervise the potential recovery of spermatogenesis in survivor spermatogonia in both the heat stressed and Nigella sativa treated mice. According to the report by Setchell (2), the recovery of spermatogenesis was encountered approximately 40 days after an exposure to heat, but our findings revealed that more than 50 days were needed to complete recovery, and treatment with Nigella sativa was able to decrease the duration of recovery.

In conclusion, dietary supplementation of ground Nigella sativa induced favourable effects on testes of scrotal heat stressed mice, and that the beneficial effects were attributable to its antioxidative and androgenic effects. Therefore, the use of Nigella sativa in heat-induced testicular damage is supported, however the precise active substance(s) of Nigella sativa, site(s) and cellular and molecular mechanism(s) of its pharmacological effect are still to be determined.

\section{References}

1. Chandra A, Stephen EH. Impaired fecundity in the United States: 1982-1995. Fam Plann Perspect 1998; 30 (1): 34-42.

2. Setchell BP. The parkes lecture: heat and the testis. J Reprod Fertil 1998; 114 (2): 179-194.

3. Gnay Y, Bulut HE, Onarlioglu B, Baimoglu-Koca Y. Comparison of the effects of vasectomy and experimental cryptorchidism in rats: I. Testicular histology. Okajimas Folia Anat Jpn 1998; 75 (2-3): 61-69.

4. Chowdhury A, Steinberger E. Early changes in the germinal epithelium of rat testes following exposure to heat. J Reprod Fertil 1970; 22 (2): 205-212.

5. Ikeda M, Kodama H, Fukuda $\mathbf{J}$ et al Role of radical oxygen species in rat testicular germ cell apoptosis induced by heat stress. Biol Reprod 1999; 61 (2): 393-399.

6. Wang R, Chang JS, Zhou XM, Chen DY. Varicocele in the rat: a new experimental model. Urol Res 1991; 19 (5): 319-322.

7. Setchell BP. The effects of heat on the testes of mammals. Anim Reprod 2006; 3 (2): 81-91.

8. Paul C, Teng S, Saunders PTK. A single, mild, transient scrotal heat stress causes hypoxia and oxidative stress in mouse testes, which induces germ cell death. Biol Reprod 2009; 80 (5): 913-919.

9. de Lamirande E, Jiang H, Zini A, Kodama H, Gagnon C. Reactive oxygen species and sperm physiology. Rev Reprod 1997; 2 (1): 48-54.

10. Setchell BP, Wahab-Wahlgren A. Effects of temporary cryptochidism on the testes and the subsequent fertility of adult male rats. Proc Soc Reprod Biol 2001; 32: 15.
11. Sönmez M, Türk G, Yüce A. The effect of ascorbic acid supplementation on sperm quality, lipid peroxidation and testosterone levels of male Wistar rats. Theriogenology 2005; 63 (7): 2063-2072.

12. Kim YH, Kim GH, Shin JH, Kim KS, Lim JS. Effect of korea red Ginseng on testicular tissue injury after testicular torsion and detorsion. Korean J Urol 2010; 51 (11): 794-799.

13. D'Cruz SC, Vaithinathan S, Jubendradass R, Mathur PP. Effects of plants and plant products on the testis. Asian J Androl 2010; 12 (4): 468-479.

14. Ali BH, Blunden G. Pharmacological and toxicological properties of Nigella sativa. Phytother Res 2003; 17 (4): 299-305.

15. Padhye S, Banerjee S, Ahmad A, Mohammad R, Sarkar FH. From here to eternity-the secret of Pharaohs: Therapeutic potential of black cumin seeds and beyond. Cancer Ther 2008; 6 (b): 495-510.

16. Nagi MN, Alam K, Badary OA, al-Shabanah OA, al-Sawaf HA, al-Bekairi AM. Thymoquinone protects against carbon tetrachloride hepatotoxicity in mice via an antioxidant mechanism. Biochem Mol Biol Int 1999; 47 (1): 153-159.

17. Machmudah S, Shiramizu Y, Goto M, Sasaki M, Hirose T. Extraction of Nigella sativa L. using supercritical Co2: A study of antioxidant activity of the extract. Sep Sci Technol 2005; 40 (6): 1267-1275.

18. Famadan MF. Oxidative stability of black cumin (Nigella sativa L.), coriander (Coriandrum sativum L.) and niger (Guizotia abyssinica cass.) Crude seed oils upon stripping. Eur J Lipid Sci Technol 2004; 106 (1): 35-43.

19. Abshenas J, Babaei H, Zare MH, Allahbakhshi A, Sharififar F. The effects of green tea (Camellia sinensis) extract on mouse semen quality after scrotal heat stress. Vet Res Forum 2011; 2 (4): 242-247.

20. Buege JA, Aust SD. Microsomal lipid peroxidation. Methods Enzymol 1984; 105: 302-310.

21. Beyer WE, Fridovich I. Assaying for superoxide dismutase activity: some large consequences of minor changes in conditions. Anal Biochem 1987; 161 (2): 559-566.

22. Aebi H. Catalase in vitro. Methods Enzymol 1984; 105: 121-126.

23. Flohe L, Gunzler WA. Assays of glutathione peroxidase. Methods Enzymol 1984; 105: 114-121.

24. Boran C, Ozkan KU. The effect of zinc therapy on damaged testis in prepubertal rats. Pediatr Surg Int 2004; 20 (6): 444-448.

25. Yin Y, Hawkins KL, DeWolf WC, Morgentaler A. Heat stress causes testicular germ cell apoptosis in adult mice. J Androl 1997; 18 (2): 159-165.

26. Ghlissi Z, Hamden K, Saoudi M et al. Effect of Nigella sativa seeds on reproductive system of male diabetic rats. Afr J Pharm Pharmacol 2012; 6 (20): 1444-1450.

27. Al-Sa'aidi JAA, AI-Khuzai ALD, Al-Zobaydi NFH. Effect of alcoholic extract of Nigella sativa on fertility in male rats. Iraqi J Vet Sci 2009; 23 (Suppl. 2): 123-128.

28. Mohammad MA, Mohamad MMJ, Dradk H. Effects of black seeds (Nigella sativa) on spermatogenesis and fertility of male albino rats research. J Med Med Sci 2009; 4 (2): 386-390.

29. Setchell BP, Ploen L, Ritzen E. Reduction of longterm effects of local heating of the testis by treatment of Rats with a GnRH agonist and an antiandrogen. Reproduction 2001; 122 (2): 255-263.

30. Babaei H, Derakhshanfar A, Kheradmand A, Bazy J. Zinc modulates heat-induced degenerative effects in mice testes. Irn J Vet Res 2007; 8 (4): 298-303. 
31. Khan VR, Brown IR. The effect of hyperthermia on the induction of cell death in brain, testis, and thymus of the adult and developing rat. Cell Stress Chaperon 2002; 7 (1): 73-90.

32. Allan DJ, Harmon BV, Kerr JFR. Cell death in spermatogenesis. In: Potten CS (Ed). Perspectives on mammalian cell death. Oxford: Oxford University Press, 1987.

33. Rockett JC, Mapp FL, Garges JB, Luft JC, Mori C, Dix DJ. Effects of hyperthermia on spermatogenesis, apoptosis, gene expression and fertility in adult male mice. Biol Reprod 2001; 65 (1): 229-239.

34. Sinha Hikim AP, Lue Y, Yamamoto $C$ et al. Key apoptotic pathways for heat-induced programmed germ cell death in the testis. Endocrinology 2003; 144 (7): 3167-3175.

35. Sinha Hikim AP, Lue Y, Diaz-Romero M, Yen PH, Wang C, Swerdloff RS. Deciphering the pathways of germ cell apoptosis in the testis. J Steroid Biochem Mol Biol 2003; 85 (2-5): 175-182.

36. Kodama H, Yamaguchi R, Fujuda J, Kasai H, Tanaka T. Increase oxidative deoxyribonucleic acid damage in the spermatozoa of infertile male patients. Fertil Steril 1997; 68 (3): 519-524.

37. Burits M, Bucar F. Antioxidant activity of Nigella sativa essential oil. Phytother Res 2000; 14 (5): 323-328.

38. Ahmad A, Husain A, Mujeeb M et al. A review on therapeutic potential of Nigella sativa: A miracle herb. Asian Pac J Trop Biomed 2013; 3 (5): 337-352.
39. Salem ML. Immunomodulatory and therapeutic properties of the Nigella sativa L. seed. Int J Immunopharmacol 2005; 5 (13-14): 1749-1770.

40. Kanter M. Nigella sativa and derived thymoquinone prevents hippocampal neurodegeneration after chronic toluene exposure in rats. Neurochem Res 2008; 33 (3): 579-588.

41. Kanter M, Coskun O, Kalayci M, Buyukbas S, Cagavi F. Neuroprotective effects of Nigella sativa on experimental spinal cord injury in rats. Hum Exp Toxicol 2006; 25 (3): 127-133.

42. Ahlbom E, Prins GS, Ceccatelli S. Testosterone protects cerebellar granule cells from oxidative stress induced cell death through a receptor mediated mechanism. Brain Res 2001; 892 (2): 255-262.

43. Al-Okbi S, Ammar NM, Abdel-Kader MN. Studies of some biochemical, Nutritional and anti-inflammatory effect of Nigella sativa seeds. Egypt J Pharm Sci 2000; 38 (4-6): 451-469.

44. Kanter M, Coskun OJ, Gurel A. Effect of black cumin (Nigella sativa) on cadmium induced oxidative in the blood of rats. Biol Trace Elem Res 2005; 107 (3): 277-278.

45. de Rooij DG, Russell LD. All you wanted to know about spermatogonia but were afraid to ask. J Androl 2000; 21 (6): 776-798.

Received February 18, 2014 Accepted February 26, 2014. 